\title{
POPULATION DYNAMICS AND EXTRACELLULAR ENZYMES ACTIVITY OF MESOPHILIC AND THERMOPHILIC BACTERIA ISOLATED FROM SEMI-ARID SOIL OF NORTHEASTERN BRAZIL
}

\author{
Krystyna Gorlach-Lira*; Henrique D.M. Coutinho ${ }^{1}$ \\ Departamento de Biologia Molecular, Centro de Ciências Exatas e da Natureza, Universidade Federal da Paraíba, João Pessoa - \\ $\mathrm{PB}$, Brasil
}

Submitted: March 10, 2006; Returned to authors for corrections: June 01, 2006; Approved: January 18, 2007.

\begin{abstract}
The dynamics of mesophilic and thermophilic bacterial population was studied in the bulk soil and rhizosphere of the grass Aristida adscensionis L. in a caatinga of the semi-arid Brazilian Northeast. Mesophilic heterotrophic bacteria, spore-forming bacteria and actinomycetes were significantly more abundant than thermophiles, and their counts were $10^{6}-10^{7} \mathrm{CFU} \mathrm{g} \mathrm{g}^{-1}$ dry soil, showing weak fluctuations over the one-year study period. Thermophiles were below $10^{6} \mathrm{CFU} \mathrm{g}^{-1}$ dry soil and, in general, demonstrated stronger fluctuations over the studied period. Among them, thermophilic actinomycetes showed the greatest decline during the dry season. No significant differences in microbial number were observed between bulk and rhizosphere soil. Mesophilic bacteria were represented mainly by Gram positive, filamentous organisms (actinomycetes) and by Gram positive, endospore-forming, rod-shaped organisms. All isolates of thermophilic bacteria were Gram positive, endospore-forming rods. Most of mesophilic isolates produced amylases and proteases, and 38\% of isolates produced all studied extracellular enzymes: amylases, proteases, cellulases and chitinases. Among thermophilic bacteria, all isolates showed proteolytic activity and $77 \%$ produced amylases, but no one produced cellulases or chitinases.
\end{abstract}

Key words: mesophilic bacteria, thermophilic bacteria, actinomycetes, extracellular enzymes, semi-arid, caatinga

\section{INTRODUCTION}

Caatinga, a dry tropical deciduous vegetation, composed by small trees, bushes and grasses, xerophiles and deciduous plants, is the largest vegetation type, which comprises approximately 845 thousands $\mathrm{km}^{2}$, in the semi-arid region of Northeast of Brazil. Some characteristics of the caatinga region are high level of insolation, high temperature, scanty hydric resources and scarce rains, that often cause long periods of drought.

Information on density and diversity of soil microorganisms is scarce under dry land tropical conditions, especially in caatinga soils. The microorganisms in the soil are strongly influenced by various chemical and physical factors, including the nutrient availability, organic matter, soil moisture and temperature $(1,22,25)$. In arid environments all these factors are usually unfavorable for microbial growth in the soil. Among physical stresses, a short-term drought may be the major stress affecting microbial population diversity and activity, due to reduced substrate diffusion in dry soils and increased microbial demands for $\mathrm{C}$ and $\mathrm{N}$ (19).

Bacteria constitute the principal group of decomposers responsible for carbon recycling, mostly because of their capacity to produce diverse extracellular enzymes that degrade complex compounds and macromolecules (10). The production of extracellular hydrolytic enzymes such as proteases, amylases, cellulases and chitinases in the semi-arid soil, characterized by limited nutrients availability, as well as the rhizospheric effect, may greatly contribute to growth and survival of bacterial population. In semi-arid tropics the thermophilic and thermotollerant bacteria may play significant role in the soil,

*Corresponding Author. Mailing address: Departamento de Biologia Molecular, Centro de Ciências Exatas e da Natureza, Universidade Federal da Paraíba, Cidade Universitária - Campus I, João Pessoa - PB. 58059-900, Brasil. Tel.: (83) 3216-7436 ou (83) 3216-7787. E-mail: krysgl@ dbm.ufpb.br 
however, there are a few reports on these microbial groups in relation to their abundance and diversity in the soil $(16,26)$.

The present study was carried out to determine the dynamics of mesophilic and thermophilic bacteria population in the bulk soil and rhizosphere of Aristida adscensionis, a naturally occurring grass at the caatinga in Brazilian Northeast. The biotypes and the extracellular enzymes activity of isolated soil bacteria were also investigated.

\section{MATERIALAND METHODS}

\section{Study site}

This study focuses on Cariris Velhos region in Paraiba State, considered one of the driest parts of Northeast Brazil. Field samples were collected at caatinga area of São João do Cariri ( $7^{\circ} 25^{\prime}$ 'S, $\left.37^{\circ} 30^{\prime} \mathrm{W}\right)$, located at $300 \mathrm{~km}$ from João Pessoa-PB. Most of the studied sites, used as natural pasture in very moderate scale, had scattered woody and herbaceous vegetation dominated by Aspidosperma pyrifolium Mart., Croton sonderianus Muell.Arg., Opuntia spp., and Sida sp. Most of the area between the trees was colonized by grass Aristida adscensionis L. (Poaceae).

The climate of the region studied is semi-arid (Bush type), dry and hot, with dry and rainy season not well defined. Mean annual precipitation is $350 \mathrm{~mm}$, and the main rainfall occurs between February and May.

The chemical characteristics of soil (luvisol), were as follows: $1.31 \%$ total organic carbon, $<0.01 \%$ total nitrogen, $3.33 \% \mathrm{Ca}$, 4.42\% Mg, $2.29 \% \mathrm{Na}, 3.91 \% \mathrm{~K}, 0.01 \% \mathrm{P}$; pH 6.8.

The precipitation of the period (October 1997 - August 1998) was $121 \mathrm{~mm}$, where among six sampling times, the monthly rainfall was as follows: October - 0, November - 0, December - 3, January - 3, February - 10, March - 0, April - 10, May - 10, June - 25, July - 20 and August - $40 \mathrm{~mm}$ (data from Civil Engineering Department of Federal University of Paraiba). The total annual precipitation of 1997 and 1998 were $448 \mathrm{~mm}$ and $118 \mathrm{~mm}$, respectively.

\section{Sampling and soil analysis}

Bulk soil samples were collected at the $0-10 \mathrm{~cm}$ depth in the interspaces between trees in the sites that lack vegetation. Each soil sample was a mixture of five sub-samples taken randomly in the selected area of $20 \times 20 \mathrm{~m}$. Simultaneously, the roots of grass A. adscensionis with adhering soil were collected and transported to the laboratory in sterile plastic bags for further processing. Samples of bulk soil and rhizospheric soil were collected every two months during one year (October 1997 August 1998).

The soil temperature was measured at 2 and $10 \mathrm{~cm}$ depth in the sampling sites, always at the same day period (noon). The percent moisture and soil $\mathrm{pH}$ were determined according to Foster (6).

\section{Counts of mesophilic and thermophilic bacteria}

The number of mesophilic and thermophilic culturable heteretrophic bacteria, spore-forming bacteria and actinomycetes were determined by plating serial dilutions of the soil on agar media. The incubation of microorganisms were carried at $30^{\circ} \mathrm{C}$ and $55^{\circ} \mathrm{C}$ for mesophilic and thermophilic cultures, respectively. Total heterotrophic bacteria were enumerated and isolated on the yeast extract - peptone - soil extract medium (YPS) (3) and on 100-times diluted nutrient broth agar medium (DNB) (8), after 12 days of incubation. Spore-forming bacteria were plated on modified nutrient agar medium (NB/SF) according to Holt and Krieg (11), using dilutions of soil heated at $80^{\circ} \mathrm{C}$ for 10 minutes, and counted after 5 days of incubation. Mesophilic actinomycetes were enumerated on modified yeast extract glucose medium (YGA) (4) and thermophiles on YGM medium containing yeast extract - $0.05 \%$; D - glicose - $0.05 \%$; malt extract $-0.1 \% ; \mathrm{K}_{2} \mathrm{HPO}_{4}-0.05 \% ; \mathrm{MgSO}_{4} \cdot 7 \mathrm{H}_{2} \mathrm{O}-0.005 \% ; \mathrm{FeSO}_{4} \cdot 7 \mathrm{H}_{2} \mathrm{O}-$ $0.001 \%$; agar $-1.5 \%$, after 12 days of incubation. The analysis of thermophilic actinomycetes counts began at second sampling time (December). All results were expressed as log of colony forming units (CFU) per gram of oven-dried soil at $105^{\circ} \mathrm{C}(\log$ $\mathrm{CFU} / \mathrm{g})$.

The rhizosphere effect (R/S ratio) for each microbial group was calculated.

\section{Characterization of bacteria isolated from bulk and rhizospheric soil}

Forty three isolates of mesophilic and 34 isolates of thermophilic bacteria were isolated on DNB medium from bulk and rhizospheric soil. The strains were characterized using Gram staining performed by Hucker modification (5) and catalase and oxidase production (20). For testing spore formation, aged culture cell suspension was heated at $80^{\circ} \mathrm{C}$ for $10 \mathrm{~min}$ and inoculated on DNB agar medium supplied with $1 \%$ of yeast extract (Difco). The isolates were tested for growth in fullstrength nutrient agar (NB) medium. Bacteria were inoculated on both NB and DNB media and incubated for 7 days at $30^{\circ} \mathrm{C}$ (mesophiles) and $50^{\circ} \mathrm{C}$ (thermophiles). Bacteria grown on the NB medium were grouped as NB organisms and considered as copiotrophs. Bacteria able to grow only on DNB medium were grouped as DNB organisms and tentatively considered as oligotrophs (23). The bacterial isolates were tested for growth at temperature ranging from 25 to $70^{\circ} \mathrm{C}\left(5^{\circ} \mathrm{C}\right.$ intervals $)$ on DNB agar medium supplied with $0.1 \%$ yeast extract (Difco) incubated for 7 days. For each isolate the optimum, maximum, and in some cases, minimum growth temperatures were determined.

\section{Production of extracellular enzymes by bacterial isolates}

Agar medium screening test was used to analyse cellulolytic, proteolytic, amylolytic and chitinolytic activity of isolates. Mesophilic and thermophilic isolates were incubated at $30^{\circ} \mathrm{C}$ and $50^{\circ} \mathrm{C}$, respectively. 
Cellulolytic activity was determined on agar medium with $0.1 \%$ carboxymethylcellulose (Sigma) according to the method of Teather and Wood (24). Chitinolytic activity was evaluated on agar medium composed by $0.5 \%$ dry mass of colloidal chitin (Difco), $0.1 \% \mathrm{NH}_{4} \mathrm{Cl}, 0.1 \% \mathrm{~K}_{2} \mathrm{HPO}_{4}, 1 \mathrm{ml}$ of trace elements ( $0.1 \%$ solution of $\mathrm{FeSO}_{4} \cdot 7 \mathrm{H}_{2} \mathrm{O}, \mathrm{MnCl}_{2} \cdot 4 \mathrm{H}_{2} \mathrm{O}$, and $\left.\mathrm{ZnSO}_{4} \cdot 7 \mathrm{H}_{2} \mathrm{O}\right), 1.5 \%$ agar (pH 7.0). Colloidal chitin was prepared according to Lingappa and Lockwood (15). After 15 days of incubation, the depth of the clear medium in the tubes was measured ( $\mathrm{mm}$ ). Amylolytic enzymes production was tested on the medium with $0.2 \%$ of starch (Difco) according to Smibert and Krieg (20). The composition of medium for screening proteolytic activity was as follow: $2 \%$ gelatine (Difco), $0.01 \% \mathrm{NaCl}, 0.05 \% \mathrm{~K}_{2} \mathrm{HPO}_{4}, 0.02 \%$ $\mathrm{MgSO}_{4} \cdot 7 \mathrm{H}_{2} \mathrm{O}$, trace $\mathrm{FeSO}_{4} \cdot 7 \mathrm{H}_{2} \mathrm{O}, 0.01 \% \mathrm{CaCl}_{2}, 1.5 \%$ agar $(\mathrm{pH}$ 7.0). After 4 days of incubation, the zones of gelatine hydrolysis were measured after previous flooding with Frazier's reagent (15.0 $\mathrm{g} \mathrm{HgCl}_{2}, 20 \mathrm{ml}$ concentrated $\mathrm{HCl}, 100 \mathrm{ml}$ distilled water).

\section{Statistical analysis}

The one-way analysis of variance (ANOVA) was performed on the plate count data ( $\log \mathrm{CFU} / \mathrm{g}$ ) analysing the following factors: soil type (bulk, rhizospheric), microbial group (mesophiles, thermophiles) and culture medium (DNB, NB). Comparisons having significant $\mathrm{F}$ values $(p \leq 0.01)$ were further compared using Tukey's HSD test. Mean values and standard errors for counts were generated for each bacterial group. The software used for computation of statistics was Statistica for Windows (version 5.1, StatSoft, Inc. Tulsa, OK).

\section{RESULTS}

\section{Population dynamics of mesophilic and thermophilic bacteria in soil}

Figure 1 shows the values for soil temperature and moisture over the study period. The soil temperature was always over $31^{\circ} \mathrm{C}$ and reached the highest values, 57 and $52^{\circ} \mathrm{C}$ at 2 and $10 \mathrm{~cm}$ depth, respectively, on February (dry season). Only in June and August, characterised by higher rainfall, were detected lower soil temperatures $\left(31-36^{\circ} \mathrm{C}\right)$. The soil moisture was very low, ranging from $0.1 \%$ (dry season) to $3.1 \%$ (rainy season). There were no significant differences in moisture between the bulk and rhizospheric soil.

Each group of mesophilic and thermophilic bacteria in the caatinga bulk soil and A. adscensionis rhizosphere showed characteristic pattern of density fluctuations. The number of mesophilic bacteria varied from 6.7 to $7.7 \log \mathrm{CFU} \mathrm{g}{ }^{-1}$ of soil, while the thermophilic bacteria were less numerous, showing the counts from 4 to $5 \log$ CFU g-1 (Fig. 2). Thermophilic culturable heterotrophic bacteria were significantly more numerous on DNB medium than on YPS medium,

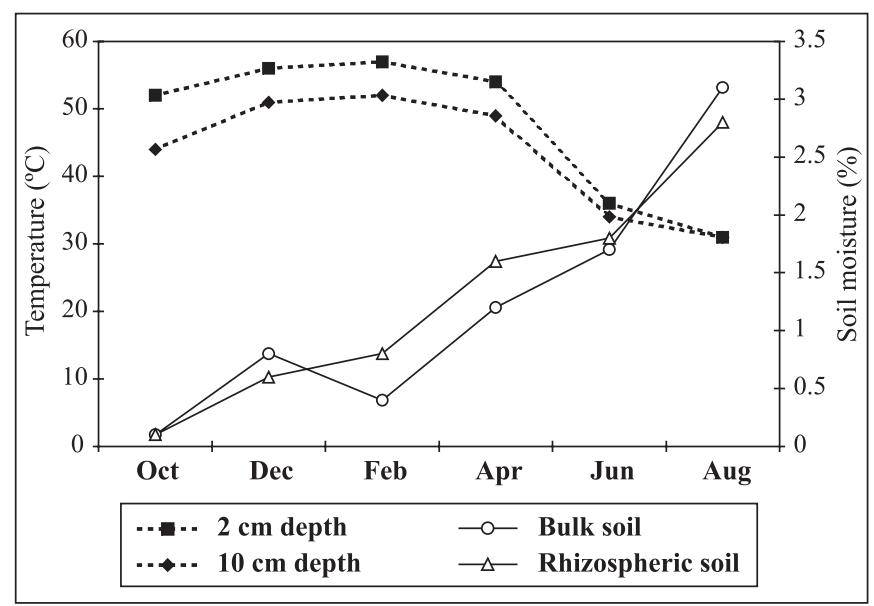

Figure 1. Temperature of soil in situ at 2 and $10 \mathrm{~cm}$ depth and moisture of soil samples.

but only those isolated from bulk soil. The counts of mesophilic bacteria were similar in both media (Fig. 2 and 3). Thermophilic bacteria showed higher fluctuations in their number over the period (Fig. 2). Significant decline of their counts, from 6.5 to 4.1 $\log$ CFU g ${ }^{-1}$ on DNB medium, was observed in February.

The counts of mesophilic actinomycetes and spore-formers were similar and averaged 6.5 - 6.7 $\log \mathrm{CFU} \mathrm{g}{ }^{-1}$ and 6.0-6.1 log $\mathrm{CFU} \mathrm{g}^{-1}$, respectively (Fig. 2 and 3). The abundance of mesophilic members of these groups was significantly higher than thermophiles in all samples (Fig. 3). Among bacteria analysed, the thermophilic actinomycetes showed the most significant decline in February and April in both bulk and rhizospheric soil samples (Fig. 2).

There were no significant differences between the number of any bacterial group in bulk and rhizospheric soil (Fig. 3). The rhizospheric effect of $A$. adscensionis was more pronounced in case of thermophiles than mesophiles (Table 1). The greatest

Table 1. Rhizospheric effect (R/S ratio) of A. adscensionis on mesophilic and thermophilic bacteria.

\begin{tabular}{ccccc}
\hline R/S values & \multicolumn{2}{c}{ Total bacteria } & Actinomycetes & $\begin{array}{c}\text { Spore-forming } \\
\text { bacteria }\end{array}$ \\
\cline { 2 - 3 } & YPS & DNB & & $1.2 \pm 0.9$ \\
\hline Mesophiles & & & & 0.1 \\
Mean $\pm \mathrm{SD}^{\mathrm{a}}$ & $1.5 \pm 0.3$ & $1.4 \pm 0.6$ & $1.6 \pm 0.5$ & \\
Minimum & 1.1 & 0.6 & 0.9 & 2.3 \\
Maximum & 1.8 & 2.1 & 2.0 & \\
Thermophiles & & & & $0.5 \pm 4.0$ \\
Mean $\pm \mathrm{SD}^{\mathrm{a}}$ & $2.9 \pm 3.5$ & $1.1 \pm 0.9$ & $1.4 \pm 1.3$ & 0.1 \\
Minimum & 0.1 & 0.1 & 0.2 & 10.2 \\
Maximum & 9.2 & 2.4 & 4.0 & \\
\hline
\end{tabular}

a - Standard Deviation. 


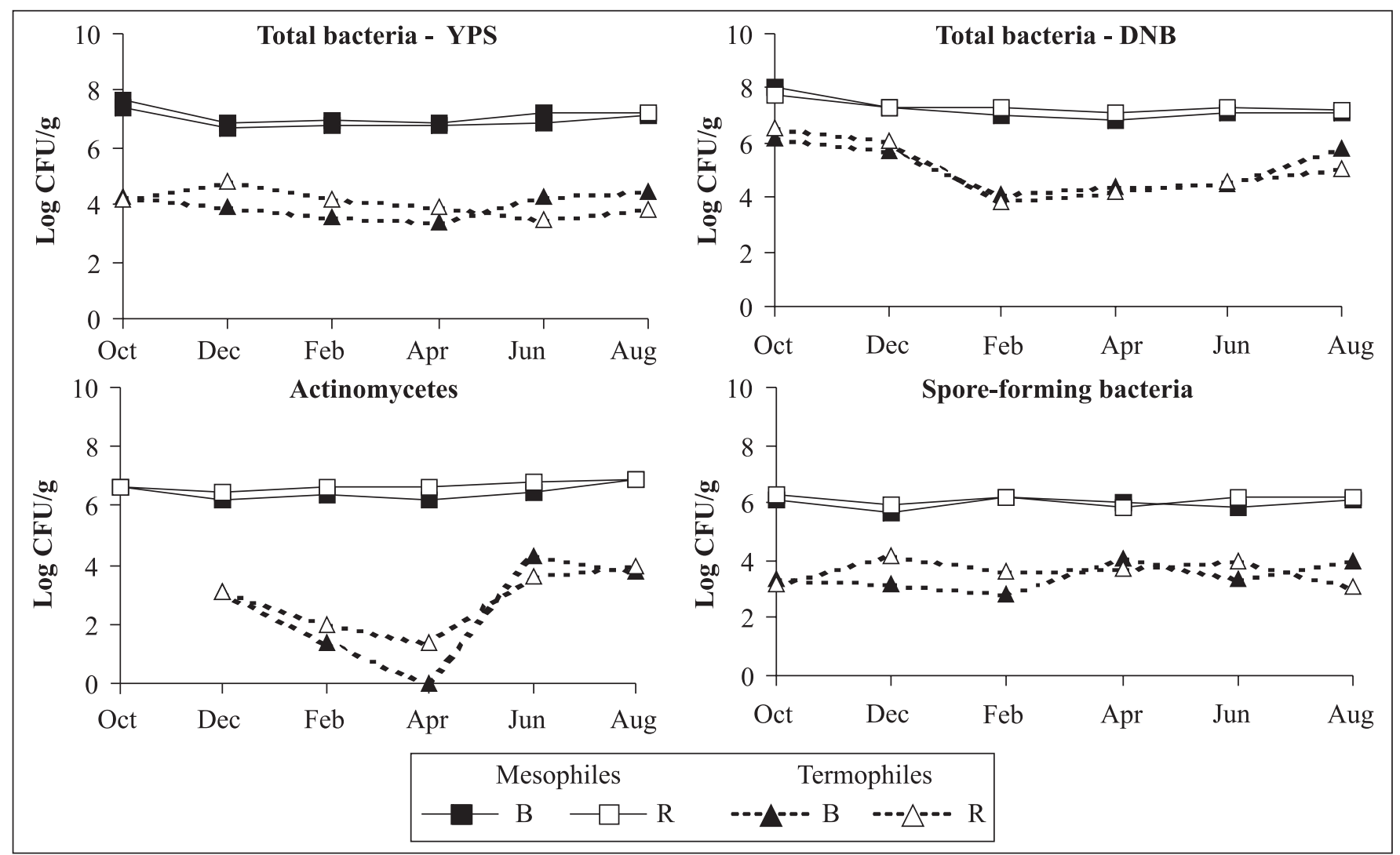

Figure 2. Dynamics of population of mesophilic and thermophilic bacteria in the bulk (B) and A. adscensionis rhizospheric (R) soil.

rhizosphere effect for thermophilic group of total heterotrophic bacteria and spore-forming bacteria was observed in December, which was one of the driest month ( $3 \mathrm{~mm}$ of precipitation).

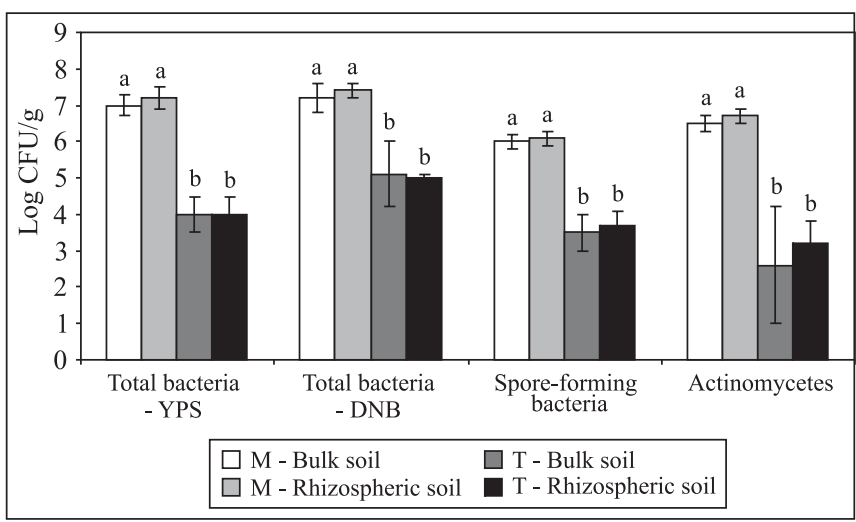

Figure 3. Mean numbers of mesophilic (M) and thermophilic (T) microorganisms in bulk soil and in A. adscensionis rhizospheric soil. Means followed by different letters are significantly different at $\mathrm{P}<0.05$ within each bacterial group.

\section{Bacterial biotypes and extracellular enzyme production}

The bacterial isolates were phenotypically characterized and grouped into five biotypes. All isolates, with excession of three, were Gram positive. Among mesophilic bacteria, actinomycetes (biotype D) were predominant (56\%) (Table 2). Endosporeforming rods (biotype B) constituted $30 \%$ of isolates, and were more frequent among isolates from root-free soil than from rhizosphere. All isolates of thermophilic bacteria were represented by only one biotype (endospore-forming rods).

The oligotrophic organisms were observed only among mesophilic bacteria (28\%), while all thermophilic isolates were copiotrophic (Table 2).

Most of mesophilic isolates grew optimally at $30^{\circ} \mathrm{C}$, and maximum growth temperature was $45-50^{\circ} \mathrm{C}$ (Table 3$)$. The bacteria isolated at $50^{\circ} \mathrm{C}$ showed optimum growth between 40 and $50^{\circ} \mathrm{C}$ and the majority of isolates grew up to $65-70^{\circ} \mathrm{C}$. Among them, 5 isolates can be considered as thermophiles sensu stricto since Tmax $>55^{\circ} \mathrm{C}$ and $\mathrm{Tmin}>30^{\circ} \mathrm{C}$ while other strains were thermotollerant, according to the Sonnleitner's classification (21).

Most of the mesophilic isolates produced amylases and proteases (Fig. 4 and 6). Production of enzymes tested was more common among endospore-forming bacteria and 


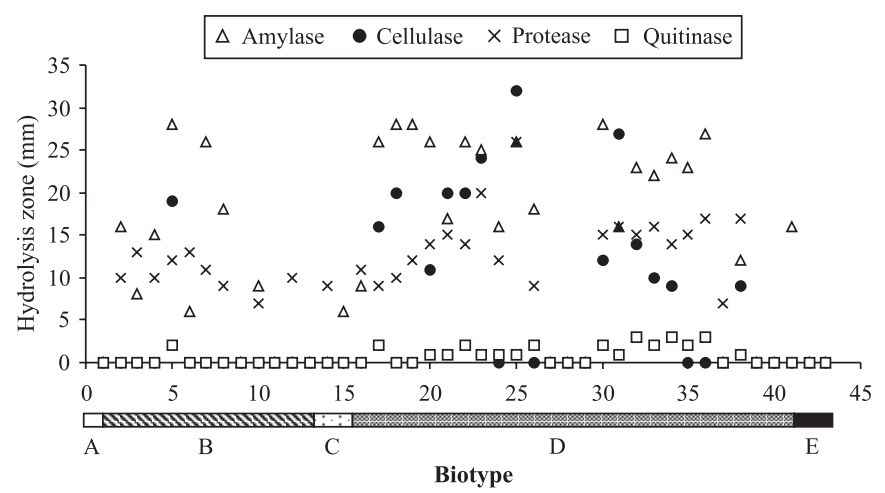

Figure 4. Enzymatic activity of mesophilic bacteria.

Table 2. Biotypes of mesophilic and thermophilic bacteria.

\begin{tabular}{|c|c|c|c|}
\hline \multirow{3}{*}{ Bacteria } & \multicolumn{3}{|c|}{ Number of strains } \\
\hline & \multirow{2}{*}{$\begin{array}{c}\text { Total } \\
(\%)\end{array}$} & \multicolumn{2}{|c|}{$\begin{array}{c}\text { Copiotrophs/ } \\
\text { Oligotrophs }\end{array}$} \\
\hline & & $\mathrm{S}^{\mathrm{a}}$ & $\mathrm{R}^{\mathrm{b}}$ \\
\hline Mesophiles & 43 & $26 / 5$ & $17 / 7$ \\
\hline $\begin{array}{l}\text { Gram positive, coccus } \\
\text { (biotype A) }\end{array}$ & $1(2)$ & $1 / 0$ & $0 / 0$ \\
\hline $\begin{array}{l}\text { Gram positive, endospore-forming, } \\
\text { rod-shaped (biotype B) }\end{array}$ & $13(30)$ & $10 / 2$ & $3 / 1$ \\
\hline $\begin{array}{l}\text { Gram positive, non-sporing, } \\
\text { rod-shaped (biotype C) }\end{array}$ & $2(5)$ & $1 / 0$ & $1 / 1$ \\
\hline $\begin{array}{l}\text { Gram positive, filamentous } \\
\text { (biotype } D \text { ) }\end{array}$ & $24(56)$ & $13 / 2$ & $11 / 3$ \\
\hline $\begin{array}{l}\text { Gram negative, rod-shaped } \\
\text { (biotype E) }\end{array}$ & $3(7)$ & $1 / 1$ & $2 / 2$ \\
\hline Thermophiles & 34 & $6 / 0$ & $28 / 0$ \\
\hline $\begin{array}{l}\text { Gram positive, endospore forming, } \\
\text { rod-shaped (biotype B) }\end{array}$ & $34(100)$ & $6 / 0$ & $28 / 0$ \\
\hline
\end{tabular}

${ }^{\mathrm{a}}$ Soil; ${ }^{\mathrm{b}}$ Rhizosphere.

actinomycetes. All substrates tested were degraded by 13 strains, that represented $50 \%$ of actinomycetes and $8 \%$ of sporeforming bacteria. Among the other isolates, only amylolytic and proteolytic activity were found. In case of thermophilic bacteria all isolates showed proteolytic activity and $77 \%$ produced amylases (Fig. 5 and 6). However, none isolate showed celullolytic and quitinolytic activity. Isolates that showed higher proteolytic and cellulolytic activity were isolated from bulk soil, while those with higher production of amylases and quitinases were from rhizospheric soil.
Table 3. Growth temperature range of mesophilic and thermophilic bacteria.

\begin{tabular}{|c|c|c|c|c|c|c|c|c|c|c|c|c|c|}
\hline \multirow{2}{*}{$\begin{array}{l}\text { Number } \\
\text { of isolates }\end{array}$} & \multicolumn{13}{|c|}{ Temperature $\left({ }^{\circ} \mathrm{C}\right)$} \\
\hline & 20 & 25 & 30 & 35 & 40 & 45 & 50 & 55 & 60 & 65 & 70 & 75 & 80 \\
\hline & & & & & & & eso & phi & & & & & \\
\hline 22 & + & + & + & + & + & + & + & - & - & - & - & - & \\
\hline 18 & + & + & + & + & + & + & - & - & - & - & - & - & - \\
\hline 3 & + & + & + & + & + & - & - & - & - & - & - & - & - \\
\hline & & & & & & & ern & op & iles & & & & \\
\hline 1 & - & + & + & + & + & + & + & + & + & + & + & + & \\
\hline 7 & & + & + & + & + & + & + & + & + & + & + & - & \\
\hline 2 & - & - & + & + & + & + & + & + & + & + & + & - & \\
\hline 10 & - & + & + & + & + & + & + & + & + & + & - & - & \\
\hline 9 & - & - & + & + & + & + & + & + & + & + & - & - & \\
\hline 3 & - & - & - & - & + & + & + & + & + & + & - & - & - \\
\hline 2 & - & - & - & - & + & + & + & + & + & - & - & - & \\
\hline
\end{tabular}

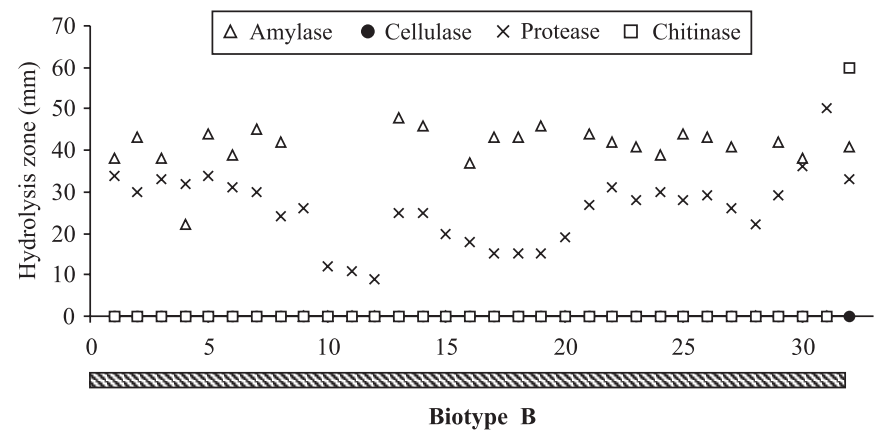

Figure 5. Enzymatic activity of thermophilic bacteria.

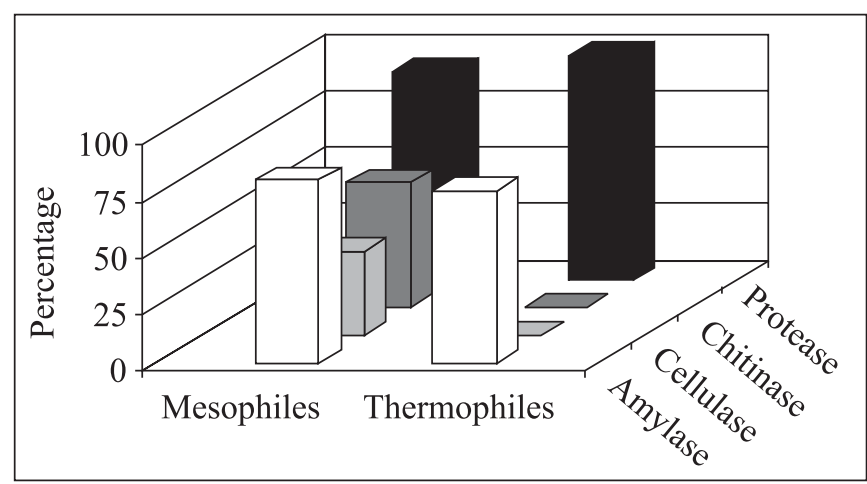

Figure 6. Frequency (percentage of the total number of isolates) of bacteria that produce extracellular enzymes. 


\section{DISCUSSION}

In the conditions of semi-arid climate, such as high temperature, low and irregular rainfall, presence of specific vegetation, high salinity and low concentration of organic matter in soil, the microbial populations are selected and stimulated seasonally according to niches structure over the year (26).

In the present work we found that the culturable microbial population in the bulk and rhizospheric soil of the grass Aristida adscensionis L. was, in general, stable along the course of the study. The mesophilic heterotrophic bacteria, actinomycetes and spore-forming bacteria were significantly more abundant than the thermophilic members of these groups.

The thermophilic bacteria were numerous in soil of caatinga, showing the counts from $10^{4}$ to $10^{6} \mathrm{CFU} \mathrm{g}^{-1}$ on different media and study sites. There are a few reports on the abundance of thermophilic microorganisms in soil. Marchant et al. (16), who studied microorganisms of cool soils of Northern Ireland, found $10^{4} \mathrm{CFU}$ of thermophiles per $\mathrm{g}$ of soil on full strength nutrient agar medium.

Thermophiles usually demonstrated stronger fluctuations over the period, and among them, actinomycetes showed the greatest decline during the drier season. The numbers of mesophilic and thermophilic actinomycetes were in the order of $10^{6} \mathrm{CFU}$ and $10^{3} \mathrm{CFU} \mathrm{g}^{-1}$ soil, respectively. Similar values were observed by Xu et al. (27) in a study on populational dynamics of mesophilic actinomycetes in the arid pasture soil $\left(1.5 \times 10^{6}\right.$ UFC $\mathrm{g}^{-1}$ ). These authors analysed also the abundance of thermophilic actinomycetes, which showed values in the order of $10^{4} \mathrm{UFC} \mathrm{g}^{-1}$, higher than found in our work. Jackson et al. (13) found that the occurrence of thermoactinomycetes was about $10^{3} \mathrm{CFU} \mathrm{g}^{-1}$ in different agricultural soils.

Despite of the commonly higher microbial density found in rhizosphere, in our study the number of microbial population did not differ significantly between bulk soil and rhizospheric soil. This was probably due to low rainfall in the period, that strongly affected the plant growth. Most of the perennial grasses, including A. adscensionis, were dry and annual herbaceous plants growth was completely inhibited. It is worth to point out that fluorescent Pseudomonas spp., often very abundant in the rhizosphere $(7,12,14)$, were not found in any sample (data not shown), showing their intolerance to the stressing conditions observed in the studied soil.

Bacteria were represented almost exclusively by Gram positive spore-forming isolates and actinomycetes. The physiological versatility of these bacterial groups and the production of spores resistant to adverse environmental conditions allow the population to survive even during periods of high stress, such as high temperature and dryness, keeping a stable population over the time (25). The actinomycetes that produce spores resistant to desiccation are common in dry soils. Borneman et al. (2) and Hattori et al. (9) also reported the predominance of Gram positive bacteria in soil. However, many authors observed that the Gram negative bacteria constitute the main bacterial group in soil $(17,18,28)$. These discrepancies may reflect the differences between climate and soil type, among other factors.

Local populations are selected by physical capacity to resist the high temperature and dryness, as well as by some specific morphological and physiological characteristics, e.g. production of particular enzymes, important factor in the environment where the nutrients availability is limited.

The bacterial strains isolated at $55^{\circ} \mathrm{C}$ were more active in producing proteases and amylases, however the bacteria isolated at $30^{\circ} \mathrm{C}$ were able to produce more diverse extracellular enzymes. Combined hydrolytic activities have been detected in various bacterial strains that could be used for biotechnological purposes. Proteolytic activity was the most common among isolates, since $93 \%$ of mesophiles and all thermophiles produced extracellular proteases. Many reports show that actinomycetes, bacteria of genera Bacillus and Pseudomonas are able to degrade chitin, however, among bacterial isolates tested in the present work, only actinomycetes produced quitinases. None thermophilic isolate showed celullolytic and quitinolytic activity. These data suggest that bacteria isolated from soil of semi-arid tropics, especially thermophilic ones, are represented by specific physiological groups. The molecular studies and quantitative analysis of extracellular enzymatic activities of these bacteria, in focus of our future work, may provide more detailed information on the diversity and biotechnological potential of bacteria that live in soil of caatinga at Northeast of Brazil.

\section{ACKNOWLEDGEMENTS}

The authors wish to thank the Conselho Nacional de Desenvolvimento Científico e Tecnológico $(\mathrm{CNPq})$ for the financial support.

\section{RESUMO}

\section{Dinâmica populacional e atividade de enzimas extracelulares de bactérias mesofílicas e termofílicas isoladas do solo do semi-árido nordestino}

A dinâmica das populações bacterianas meso e termofílicas foi estudada no solo sem raízes e rizosférico associado à gramínea Aristida adscensionis L. na caatinga da zona semiárida do nordeste brasileiro. As bactérias totais heterotróficas, as bactérias esporuladoras e actinomicetos mesofílicos foram significativamente mais abundantes que os termofílicos, suas contagens variando na ordem de $10^{6}-10^{7} \mathrm{UFC} \mathrm{g}^{-1}$ de solo seco, apresentando flutuações discretas ao longo de um período de um ano. Microrganismos termófilos foram encontrados numa ordem de $10^{6} \mathrm{UFC}^{-1}$ de solo seco e demonstraram, em geral, 
flutuações mais evidentes durante o mesmo período de estudo. Entre os termófilos, os actinomicetos apresentaram um maior declínio durante a estação seca. Nenhuma diferença significativa no número de microrganismos foi observada entre o solo rizosférico e o solo não rizosférico. As bactérias mesofílicas mais observadas foram as filamentosas Gram positivas (actinomicetos) e os bastonetes esporulantes Gram positivos. Todos os isolados termofílicos foram bactérias esporuladoras Gram positivas em forma de bacilo. A maioria dos isolados mesofílicos produziu amilases e proteases, enquanto que $38 \%$ das linhagens produziram todas as enzimas extracelulares estudadas: amilases, proteases, celulases e quitinases. Entre as bactérias termofílicas, todos os isolados apresentaram atividade proteolítica e $77 \%$ produziram amilases, mas nenhum produziu quitinases ou celulases.

Palavras-chave: Bactérias mesofilicas, bactérias termofílicas, actinomicetos, enzimas extracelulares, semi-árido, caatinga

\section{REFERENCES}

1. Bloem, J.; deRitter, P.C.; Koopman, G.J.; Lebbink, G.; Brussard, L. (1992). Microbial numbers and activity in dried and rewetted arable soil under integrated and conventional management. Soil Biol. Biochem., 24, 655-665.

2. Borneman, J.; Skroch, P.W.; O'Sullivan, K.M.; Palus, J.A.; Rumjanek, N.G.; Jansen, J.L.; Nienhuis, J.; Triplett, E.W. (1996). Molecular microbial diversity of agricultural soil in Wisconsin. Appl. Environ. Microbiol., 62, 1935-1943.

3. Bunt, J.S.; Rovira, D. (1955). Microbiological studies of some subantarctic soils. J. Soil Sci., 56, 119-128.

4. Crawford, D.L.; Lynch, J.M.; Whipps, J.M.; Ousley, M.A. (1996). Isolation and characterization of actinomycetes antagonists of a fungal root pathogen. Appl. Environ. Microbiol., 59, 3899-3905.

5. Cowan, S.T. (1974). Manual for Identification of Medical Bacteria. Cambridge University Press, Cambridge.

6. Foster, J. Determination of soil pH. (1995). In: Alef , K., Naninipieri, P. (eds.). Methods in Applied Soil Microbiology and Biochemistry. Academic Press, London, p.55.

7. Gerhadson, B.; Clarholm, B. (1986). Microbial communities on plant roots. In: Jensen, V.; Kjoller, A.; Sorensen, L.H. (eds.). Microbial Communities in Soil. London and New York.

8. Hashimoto, T.; Hattori, T. (1989). Grouping of soil bacteria by analysis of colony formation on agar plates. Biol. Fertil. Soils, 7, 198-201.

9. Hattori, T.; Mitsui, H.; Haga, H.; Wakao, N.; Shikano, S.; Gorlach, K.; Kasahara, Y.; El - Beltagy, A.; Hattori, R. (1997). Advances in soil microbial ecology and the biodiversity. Antonie van Leeuwenhoek, $72,21-28$.
10. Hendricks, C.W.; Doyle, J.D.; Hugley, B. (1995). A new solid medium for enumerating cellulose - utilizing bacteria in soil. Appl. Environ. Microbiol., 61, 2016-2019.

11. Holt, J.G.; Krieg, N.R. Enrichment and isolation. (1994). In: Gerhardt, P.; Murray, R.G.E.; Hood, W.A.; Krieg, N.R. (eds.). Methods for General and Molecular Bacteriology. ASM Press, Washington, p.179-215.

12. Ikeda, K.; Toyota, K.; Kimura, M. (1997). Effects of soil compaction on the microbial populations of melon and maize rhizoplane. Plant Soil, 189, 91-96.

13. Jackson, A.M.; Poulton P.R.; Ball, S.A. (1997). Importance of farming practice on the isolation frequency of Thermoactinomyces species. Soil Biol. Biochem., 29, 207-210.

14. Lambert, B.; Meire, P.; Joos, H.; Lens, P.; Swings, J. (1990). Fastgrowing aerobic, heterotrophic bacteria from the rhizosphere of young sugar beet plants. Appl. Environ. Microbiol., 56, 3375-3381.

15. Lingappa, Y.; Lockwood, J.L. (1962). Chitin media for selective isolation and culture of actnomycetes. Phytopathology, 52, 317-323.

16. Marchant, R.; Banat, I.M.; Rahman, T.J.; Berzano, M. (2002). The frequency and characteristics of highly thermophilic bacteria in cool soil environments. Environ. Microb., 4, 595-602.

17. Øvreas, L.; Torsvik, V. (1998). Microbial diversity and community structure in two different agricultural soil communities. Microb. Ecol., 36, 303-315.

18. Rovira, A.D. Rhizosphere research - 85 years of progress and frustration. (1991). In: Keister, D.L.; Cregan, P.B. (eds.). The rhizosphere and plant growth. Kluwer Academic Publishers. Netherlands, p.3-13.

19. Schimel, J. (1995). Ecosystem consequences of microbial diversity and community structure. Ecol. Stud., 113, 239-254.

20. Smibert, R.; Krieg, N.R. (1994). Phenotypic characterization. In: Gerhardt, P.; Murray, R.G.E.; Wood, W.A.; Krieg, N.R. (eds.). Methods for general and molecular bacteriology. ASM Press, Washington, p.607- 655 .

21. Sonnleitner, B. (1983). Biotechnology of thermophilic bacteria growth, products, and application. Adv. Biochem. Eng., 28, 69-138.

22. Subba Rao, N.S. (2001). Soil Microbiology (Fourth Edition of Soil Microorganisms and Plant Growth). Science Publishers, Inc., USA.

23. Suwa, Y.; Hattori, T. (1984). Effects of nutrient concentration on the growth of soil bacteria. Soil Sci. Plant Nutr., 130, 397-403.

24. Theather, R.M.; Wood, P.J. (1982). Use of Congo red polysaccharide interactions in enumeration of celulolytic bacteria from the bovine rumen. Appl. Environ. Microbiol., 43, 777-80.

25. Wardle, D.A. (1998). Controls of temporal variability of the soil microbial biomass: a global - scale synthesis. Soil Biol. Biochem., 30, 1627-1637.

26. White, D.; Sharp, R.J.; Priest, F.G. (1993). A polyphasic taxonomic study of thermophilic bacilli from a wide geographical area. Antonie van Leeuwenhoek, 54, 357-386.

27. Xu, L.; Li, Q.; Jinag, C.L. (1996). Diversity of soil actinomycetes in Yunnan, China. Appl. Environ. Microbiol., 62, 244-248..

28. Zelles, L.; Bai, Q.Y.; Rackwitz, R.; Winter, K.; Beese, F. (1994). Microbial biomass, metabolic activity and nutritional status determined from fatty acid patterns and poly-hydroxybutirate in agriculturally-managed soils. Soil Biol. Biochem., 26, 439-446. 